\title{
Fool's Gold: The value of Business Awards to Small Businesses
}

Dr Paul Jones, Reader in Entrepreneurship, Plymouth Business School, Plymouth University Mast House, Plymouth, PL4 0HJ, Email: Paul.Jones@plymouth.ac.uk, Tel: +44(0) 1752 585523.

Ms Joanne Scherle, Student, Business School, University of South Wales

Professor David Pickernell, Professor of Economic Development Policy, Business School, University of South Wales

Professor Gary Packham, Deputy Dean, Lord Ashcroft International Business School, Anglia Ruskin University

Dr Heather Skinner, National Teaching Fellow

Professor Tom Peisl, Professor of International Management and Strategy, Department of Business Administration, University of Applied Sciences, München, , Germany,

\begin{abstract}
This study explores the value and impact that small and medium sized enterprises (SMEs) attain from winning business awards. Value and impact are explored in terms of enhanced profitability and performance, network development, enterprise profile and brand identify. This study employed a case study methodology with 10 SMEs drawn from a major business awards competition. Key staff were interviewed in these SMEs to explore the impact of winning the business award on the internal and external business environment. Additional organisational documentation and evidence was also collected from each SME. The results indicated both short term and long term impacts. In the short term, enterprises benefited in terms of enhanced brand identity to their business network and community. This resulted in enhanced sales revenue and enterprise profile. Moreover, internally winning an award acted as a motivator for enterprise employees and enhanced their productivity and attitudes towards
\end{abstract}


the business. In the longer term, these factors become less apparent but the majority of respondents continued to exploit their business award for on-going strategic advantage.

Keywords: SME; Business awards; impact; value; performance

\section{Fool's Gold: The value of Business Awards to Small Businesses}

This study explores the value and impact that small and medium sized enterprises (SMEs) attain from winning business awards through a case study investigation. Value and impact are explored in terms of enhanced profitability and performance, network development, enterprise profile and brand identify.

\section{Literature: The impact of Business Awards}

Awards are ubiquitous across many societies and are conferred at various levels and on varying bases. Previously,, whilst Neckermann et al, (2009) recognised that there is no universally accepted definition of awards they do describe four unifying components of them, namely:

(1) the publicity value for the winners,

(2) a set of deliberately vague evaluation criteria,

(3) the unenforceability of awards, and

(4) their tournament character.

Awards are recognised as having a motivational effect incentivising desired behaviour, but also work ex-post in terms of on-going impact. Awards create and establish role models, they distribute information about successful and desirable behaviour and create loyalty' (Frey and 
Neckermann, 2008: 6). Several related prior studies (Frey 2007; Frey and Neckermann, 2008; Neckermann et al, 2010)consider the impact of awards that are conferred internally by an organisation upon its employees. Furthermore, research on the topic of psychology of internal awards has been extensively examined; especially on the effect which winning an award has on a person (Frey and Neckermann, 2008), and on the positive effect which nonmonetary awards have on employees (Magnus, 1981; Tait and Walker, 2000; Nelson, 2005). Heppner and Pew (1977) calculated the effects of diplomas and awards on perceived expertness. Additionally, there is literature available noting that a employee recognition programme in companies could significantly reduce absentee levels of employees (Markham et al, 2002). Hansen and Weisbrod (1972) and Nalebuff and Stiglitz (2001) suggest awards be considered as incentives. Moreover, Gavrila et al, (2005) describe how and the number of awards that should be applied in companies over time and how to manage the reputation of business awards.

Frey and Neckermann (2008) undertook an online survey with employees of the IBM research laboratory note the difference between individual awards bestowed at a national level and 'business awards' which they define as referring to 'awards handed out for private sector activities and comprise a diversity of honours such as "Most Powerful Woman" or "Manager of the Year", but these, again, even when bestowed externally, are conferred upon an individual and not upon an organisation. Thus pointing to a gap in our understanding of a full range of business awards, as even the literature regarding awards in the economy tends to focus on individual awards, rather than awards bestowed on an organisation. Business awards are becoming increasingly established within the corporate world to motivate both organisations and employees (Ichniowsky and Shaw, 2003). Neckermann et al, (2010) in a study of a Fortune 500 financial services provider discovered that social incentives, like 
awards, have a large positive impact on employee performance. In particular, social awards can have a positive impact on the working climate of a company (Neckermann et al, 2009). However, overall there is a lack of extant literature regarding business awards and their organisational impact. Pratt (2007: 16) argues that within the corporate world 'awards are nearly always sideshows to the real business competition', in particular that activity focused around profit, market share and business sustainability. In addition, Frey and Neckermann (2007) state that awards do not receive significant attention in the economy, even though they are widely available.

This study aims to address this gap in the literature, by examining awards that are conferred within corporate sectors of market economies, specifically within SMEs, and will consider all types of business or corporate awards for any level of competence awarded to an SME. This study considers only those awards conferred upon an organisation by an external body. The study does not consider individual employee awards conferred internally. In the context of this paper, business awards are therefore seen as awards with the characteristics described by Neckermann et al, (2009) above, when conferred upon an organisation. There has been some recognition of such awards within the literature, however, the extant literature is both limited and dated. For example, Dana (1988: 64) recognised the potential of small business awards conferred by the Australian Department of Industry, Trade and Commerce to 'reward successful, independent owner-managed small businesses. The judging panel looks for all-around achievement using the following guidelines: improved financial position (i.e., increased profitability and asset growth); innovativeness of products or services offered; and continued growth in increased value or volume of sales and employment levels'. 


\section{Business Awards and the Small and Medium Sized Enterprise Sector}

Within the UK, according to the Department of Business Innovation and Skills (2011) 99.2 per cent of all private sector business are small, 0.7 per cent are medium sized and only 0.1 per cent are large. Therefore, a significant majority of 99.9 per cent of all private sector businesses in the UK are SMEs. SMEs furthermore account for 58.8 per cent of employment and 48.8 per cent of turnover in the UK private sector (DBIS, 2011). Given their significance to economic prosperity and development it is important that effective activity of the SME community is similarly recognised and rewarded within the UK. Therefore, business awards within the UK targeting SMEs should be a means of recognising achievement and encouraging further sector growth and innovation.

Business awards targeting SMEs can also be seen to offer an indicator of "cue-based trust'. In online settings, this is of particular importance for small retailers who may not be able to offer other indicators through, for example, their size or brand name, by which to gain consumers' trust, where the conferment of an award indicates to a potential target marketer that a small business is one that is trustworthy with which to engage. Wang et al, (2004) therefore find that awards conferred by external (and therefore, importantly, neutral) sources have the capability of assisting a small business develop its public image and reputation. 'Some online retailers invest in Web-page banners showing their awards, thus signalling their reputation. Compared with self-boasting information (e.g., size or scale information, customer testimonials, etc.), awards are more effective at signalling reputation because the source of information is an important cue that will influence the believability' (Wang et al, 2004: 58). For example, in the brewing industry several major brands (e.g. Cobra, Heineken, and Stella Artois) use prior awards to highlight the quality of their product to the consumer on their brand labels. 
However, in this context Wang et al, (2004: 59) define such external 'neutral sources' as those such as awards conferred by government, rather than awards that are bestowed by external yet commercial organisations. Wang et al (2004) study identified that consumers cue-based trust in small online retailers was positively influenced by receiving awards from neutral sources. This is an interesting finding especially when compared with the lack of effect of seals of approval had in engendering such trust, as such seals of approval are not perceived of by consumers as being as neutral as awards.

\begin{tabular}{|c|c|}
\hline Study & Benefit Achieved \\
\hline Boulter et al, (2005) & $\begin{array}{l}\text { 1. improved financial performance } \\
\text { 2. greater increase in sales than competitors. }\end{array}$ \\
\hline $\begin{array}{l}\text { Great Place to Work Institute } \\
\text { (2012) }\end{array}$ & $\begin{array}{l}\text { 1. received more qualified applicants for vacancies } \\
\text { 2. less staff fluctuation } \\
\text { 3. reduced company healthcare cost } \\
\text { 4. higher customer satisfaction and loyalty } \\
\text { 5. higher efficiency, creativity and innovative strength. }\end{array}$ \\
\hline $\begin{array}{l}\text { Hendricks and Singhal } \\
\text { (1996) }\end{array}$ & $\begin{array}{l}\text { 1. increased stock market value impact } \\
\text { 2. impact is more significant when awarded by an } \\
\text { independent organisation. }\end{array}$ \\
\hline $\begin{array}{l}\text { Institute of } \text { Credit } \\
\text { Management (The Queens } \\
\text { Awards for Enterprise } \\
\text { Magazine, 2012) }\end{array}$ & $\begin{array}{l}\text { 1. an enhanced recognition in international markets } \\
\text { 2. added commercial value } \\
\text { 3. a rise in levels of employee engagement } \\
\text { 4. additional press coverage. }\end{array}$ \\
\hline Wilson (2004) & $\begin{array}{l}\text { 1. improved competitiveness } \\
\text { 2. increased customer awareness } \\
\text { 3. financial gain. }\end{array}$ \\
\hline Zahorsky (2012) & $\begin{array}{l}\text { 1. increase in credibility and awareness which leads to } \\
\text { higher sales } \\
\text { 2. attraction and retention of talent } \\
\text { 3. free publicity and expansion of public relations } \\
\text { 4. gain more recognition and credibility in the market. }\end{array}$ \\
\hline
\end{tabular}

Table 1: Impacts of Business awards

. Table 1 summarises the key benefits identified by organisation from winning a business award. As can be seen, a wide range of potential benefits can result from a business award including increased sales, employee engagement and enhanced customer recognition. The above research may lead to the suggestion that the impact or value of winning an award for 
SMEs is similar to the impact or value for all kinds of companies. However, while Pratt (2007) points out that business awards can provide good publicity and are great for employee morale, in contrast, they are often regarded with uncertainty when it is unclear how many entries were involved and if the judges were capable of making an appropriate decision. Pratt furthermore illustrates that a problem concerning business awards is that there are too many different awards and the public gets confused as to their meaning and value.

Thus in conclusion, it can be seen that despite an on-going proliferation of business awards the literature examining their impact remains limited and superficial especially in the context of organisation focused studies. This study attempts to fill this gap by exploring the impact of business awards in the context of the SME. This is illustrated in a conceptualisation of the key literature represented in Figure 1. The framework illustrates the potential impacts of winning a business award on SMEs, separated into micro and macro impacts.

\section{See Figure 1 here}

Therefore the key and overarching research question that will be explored within this study is:

Does winning a business award provide value and impact for a SME?

The next section will outline the methodology employed to analyse the research question in depth. 


\section{Methodology}

Case research was selected as the optimum method of exploring the impact of business awards within SMEs due to its tradition of providing rich contextual data and allowing indepth examination of the subject material (Jones et al, 2013). Chau (2003) supports the use of a case study interpretative approach to capture in-depth information regarding beliefs, actions and experiences of SMEs (Cavaye, 1996). Schlenker and Crocker (2003) proposed a qualitative approach as particularly relevant in exploring SME experience. Thus, the case study method enabled the "how" and "why" questions to be asked, to understand the nature and complexity of the processes taking place (Benbasat et al, 1987). Case studies have been criticised as giving rise to anecdotalism (Smith, 1991) and not maintaining researcher objectivity (Salkind, 2003). These issues were overcome by constructing a case study protocol as per Yin's (1994 guidelines.

\section{Case Study Protocol}

The objective of this case study research was to investigate the impact and value of business awards for SMEs. The unit of analysis were the selected SMEs (Rowley, 2002). The data collection method was semi-structured interviews and additional evidence collected from owner/managers/ of the SMEs through a questionnaire and other organisational material related to the business award (e.g. website, organisational correspondence, media articles). The interview was conducted personally or through telephone. To increase the flexibility of the research, owner/managers could complete the questionnaire electronically as well and send it back to the author/s. Additionally, the business award provider was interviewed to get an increased understanding of the award and their motivations. The case study objective was to investigate SME owner/managers understanding and perceptions regarding the impact of winning a business award (Voisey et al, 2005). The evidence was collected from SMEs 
owner/managers or identified representatives through semi-structured interviews (Partington, 2002). To enable the authors to answer the research question previously stated, the following topics were considered within each case:

1. How the SME achieved the award.

2. Identify the key characteristics of SMEs that have successfully exploited the winning of a business award.

3. To understand SMEs perceptions about the process to achieve an award.

4. Evaluate the value and impact SMEs obtained from winning a business awards.

Establish what are the micro and macro business benefits for a SME attained from winning a business award? The semi structured questions were developed from the topics identified above. The key element of the protocol were the questions reflecting the inquiry. A semistructured research instrument was developed with a set of open ended questions (Partington, 2002) enabling the respondents to discourse on the topics (Johannessen et al, 1999). These questions were utilised as prompts for each interview, ensuring no variation from the research foci (Poon and Swatman, 1999). The case study report involved a staged approach of assembling raw data, constructing a case record and narrative (Patton, 1990) which outlined final content and layout of each case study against the topics identified previously.

For each enterprise, a case study report was constructed, whereby the data was collected, analysed and synthesized. Each case study was cross-compared utilising a qualitative methodology to identify converging and contrasting evidence. Ten case studies were selected, the rationale for this number being prior best practice identified within SME studies (Darke et al, 1998; Jones et al, 2013). The case studies were selected on the criteria that they were an SME by definition and had previously won a South Wales Chamber of Commerce (SWCC) Business Award within the last five years. Thietart et al, (2001) identified this 
phenomenon as theoretical replication, whereby each case produced different results for predictable reasons.

The SWWC is a business support organization which is part of a UK network of nonprofit organisations set up to support British businesses. SWCC members receive information, advice, guidance, training, development and representation. Furthermore, they provide a networking infrastructure for members and represent their views on regional and national levels. The ten participating SMEs were winners of a SWCC Business Award. The SWCC Business Awards includes 10 different categories including the Welsh Company of the Year, Most Promising Growth Business, International Company of the Year, Environmental Recognition Award, Excellence in Technology Application, Award for Skills and People Development, Excellence in Marketing and Award for Manufacturing Excellence and Diversification. The following section presents the key research findings.

\section{Findings}

The respondent SMEs were all Welsh companies and prior winners of a SWCC business award. They ranged in number of employee from 13 and 63 with an average of 45 . Respondent SMEs were selected from a range of industries to provide a wider perspective of impact The SMEs were all founded within the last 30 years and half of them for less than ten years. On average, every respondent had won around ten different business awards over the preceding five years. The average turnover of the respondent SMEs was $£ 4.18$ million per SME with a range of performance between 1.7 and 8.5 million pounds. 


\begin{tabular}{|l|l|l|l|l|}
\hline Company ID & $\begin{array}{l}\text { Employee } \\
\text { Number }\end{array}$ & $\begin{array}{l}\text { Business } \\
\text { Activity }\end{array}$ & $\begin{array}{l}\text { Business } \\
\text { Turnover }(£ \\
\text { mill) }\end{array}$ & Founded \\
\hline A & 13 & Driver Training & 1.7 & 2007 \\
\hline B & 63 & $\begin{array}{l}\text { Sleeping bag } \\
\text { manufacturer }\end{array}$ & 4.9 & 2009 \\
\hline C & 45 & $\begin{array}{l}\text { Farming and } \\
\text { leisure services }\end{array}$ & 5.1 & 1983 \\
\hline D & 58 & Retailer & 2.6 & 2006 \\
\hline E & 22 & $\begin{array}{l}\text { Environmental } \\
\text { Services }\end{array}$ & 5.5 & 2010 \\
\hline F & 50 & $\begin{array}{l}\text { Construction } \\
\text { Services }\end{array}$ & 1.6 & 2008 \\
\hline G & 30 & $\begin{array}{l}\text { Consumer Data } \\
\text { specialisation }\end{array}$ & 5.1 & 2000 \\
\hline H & 50 & $\begin{array}{l}\text { Design and } \\
\text { development of } \\
\text { instrumentation }\end{array}$ & 7.0 & 2008 \\
\hline I & 62 & Metal finishing & 6.0 & 1998 \\
\hline J & $\begin{array}{l}\text { Electrical } \\
\text { system } \\
\text { integration }\end{array}$ & 8.5 & \\
\hline
\end{tabular}

Table 2: Demographic of Case Study Participants

Application Process for a business award

The majority of the interviewed owner/managers/ regarded the process to win the business award of the SWWC as demanding, but not overly challenging. Several respondents illustrated the difficulty in explaining everything their organisation had achieved succinctly. Enterprise D suggested that the application process could be improved by enhanced communication between the SWCC and the award applicants. A further recommendation to improve the process was the usage of face-to-face interviews with the applicants. Moreover, it was suggested that the business award provider should visit the applicants to attain a more informed understanding and interview both managers and employees. Enterprise E identified that the process to win a business award was time-consuming and a significant amount of organisation research and time was required to amass the information for the entry questionnaire. 


\section{Award ceremony and first promotion}

All interviewed owner/managers attended the SWCC award ceremony. The award ceremony was seen as a positive and worthwhile event. Enterprise B identified that senior managers attended the award ceremony which provided excellent networking opportunities. Furthermore, it was noted that the majority of owner/managers took staff or clients to the ceremony and attended with up to ten persons. Immediately upon winning the award, all SMEs promoted the event using different marketing and public relation media. Typically these included press releases to local, regional and national newspapers/magazines, website announcements, social media and internal announcements. Internal organisation announcements (through email, social media, newsletter and intranets) were employed to increase the feel-good factor and inclusion of employees. Press releases (through local, regional and national newspapers) and social media were the most employed tool to promote the business award immediately upon winning.

\section{Impact of winning the business award}

The respondents were asked how they measured the impact of winning a business award in general. Overall, all interviewees judged the impact upon their enterprises as between moderate and highly significant. The respondents were thereafter asked to clarify internal impacts/values and external impacts/values.

\section{Business Internal Impacts}

Winning a business award was identified as having a moderate impact on employee satisfaction post event. Two respondent enterprises (A and I) stated that there was no impact, 
whereby Enterprise G suggested that the impact on employee satisfaction was highly significant as indicated by the following comment:

"Awards are a good booster and congratulations show employees that what they are doing is good and they get recognition. There was a lot of positive discussion regarding the award amongst employees they saw it as a sign that the business was thriving and successful. This builds confidence internally”

A "feel-good" factor for employees was mentioned as well as the personal and organisational pride gained by winning business awards. Regarding employee motivation, the response was similar. The impact of winning a business award on employee motivation was seen as moderate. A range of opinions were apparent. Enterprise $\mathrm{H}$ experienced a highly significant impact on employee motivation, whereby (E and I) did not. The positive respondent was illustrated as follows:

"Our Staff were pleased and there was a buzz around the office. The employees seemed to take more ownership of the company following the award"

According to Enterprise H, his employees were more motivated and confident in what they were doing since winning the business award. However, the majority of the interviewed respondents did not experience any change in the quality or quantity of applications from potential employees with the exception of Enterprise J. The business award was listed on the website and social media (Facebook and Twitter) and therefore seen by potential candidates who referred to it during their interview. Finally, all respondent SMEs agreed that there was no impact of winning a business award on new product/service development. 


\section{Business external impacts}

The winning of a business award could have external impacts on the wider environment. Potential external impacts include changes in customer/supplier network and development, business profile and brand identity. Half of the SMEs experienced an increase in turnover after winning the business award. The remaining SMEs did not perceive any significant impact of winning a business award on turnover. Enterprise F suggested that the economic recession had begun after winning the business award, which could have been a contributory factor towards negative growth. Regarding profitability, all SMEs agreed that winning a business award did not have any significant impact on the company's profitability. By contrast, all respondent SMEs, with one exception, confirmed that their customer network and development did improve after winning a business award. All the SMEs received positive feedback from customers regarding winning a business award. For example, it was identified that clients commented or mentioned the business award in conversations with employees. However, Enterprise $\mathrm{C}$ argued as follows:

"We had initially thought that we could use the winning of this award to attract and develop a larger customer base and help us network but this never materialised. It seemed to be a short term effect. Maybe we did not do enough to promote the award."

When considering supplier network and development, the SMEs did not perceive any change upon winning a business award. Only Enterprise $\mathrm{G}$ experienced a moderate improvement in their supplier network and development. Enterprise $\mathrm{H}$ identified that their business profile had improved significantly following the business award. However, half of the SMEs did not 
perceive any impact on their business profile. The positive impact on brand identity was recognized by all SMEs with one exception (Enterprise I), as a moderate to highly significant positive impact. When asking for any other short or long-term impacts that the SMEs experienced, increased press coverage was specifically identified. Enterprise E, a relatively young SME with its stated:

"I would say that press coverage was more of a short term impact with the staff moral and the initial pleasure and excitement of the wining of the award. However, we received excellent coverage in local newspapers and on social media for 48 hours following the award. “

Another impact identified was increased contact from suppliers seeking to sell their products/services. However, Enterprise F suggested that this was not very useful and generally a waste of time. In conclusion, the respondents agreed that the impact was difficult to measure, Enterprise J stated:

"We all hope that it is promoting our business profile and that we gain more customers through it. However, it is very difficult to gauge its true value."

Other factors reported by the respondents was the assistance in benchmarking, opportunity for networking, the public relations value and the increasing job satisfaction for employees. Furthermore, winning a business award was seen as valuable for enhancing corporate documents and reports that might be provided to clients and stakeholders. When asking for an impact on the local, national, European or international trading markets due to winning the 
business award, the SMEs answered consistently that they had not perceived any noticeable impact.

\section{Marketing aspects}

All SMEs promoted the business award on their company website and via social media outlets. Either the SWCC logo was used on the website or there was a dedicated section explaining the award. Furthermore, SWCC logos or information about the award was used on the signature of emails or to contact new clients. Half of the interviewed SMEs put out publicity in print and online. Enterprise $G$ obtained a special public relations company working on their behalf to promote the winning of the award immediately after the final and thereafter.

\section{Desired support and ideal business award}

To extend their products or services into new markets, several of the SMEs indicated that they would require enhanced financial support. Enterprise B stated that financial assistance was of immense importance to identify and make introductory visits to new international markets of interest. Furthermore, a stronger customer/client base to demonstrate the products/services to a wider audience was also of great value. However, financial support was the most mentioned factor when discussing possible support issues. The financial aspect was also an important element when talking about the "ideal business award" for SMEs. Enterprise A saw the ideal business award as one: 
"with a large cash prize and massive exposure. Business awards would be far more meaningful if they came with such an incentive. It would really help us growth the business to another level“

Enterprise B suggested an award:

"that provides both, credibility and assistance (financial and/or in kind) to promote the business to relevant niche business sectors or territories, particularly internationally."

An important consideration for the ideal business award was the coverage of different categories. Enterprise E and I suggested that "Education and Training" and "Green awards" were important issues which provided the greatest status benefit for their businesses.

\section{General issues}

All the respondents viewed business awards in general as positive. All would apply again for a business award based on their prior experience.. They regarded business award applications as a worthwhile activity. When applying again the SMEs identified that they would carefully select the most appropriate award for them in terms of retaining value to the business. However, the SMEs agreed that the external impact was more difficult to evaluate and ascertain, whereby the internal impact was regarded as valuable.

"Awards increase the job satisfaction and the whole company can benefit from them." (Enterprise D) 
This statement effectively summarised the respondent opinion of regarding business awards. The public relations value was seen as significant, as well as the opportunity for networking. Enterprise E suggested that they would wait for another year before a further award application as they believed that the market would increase and the business would benefit from reaching a wider audience of potential customer/clients.

\section{Business award provider}

The business award provider in this study was the SWCC. All quotes and statements in this section were based on an interview with the Director of the SWCC. The award provider was interviewed to establish the motivation and rationale for providing such awards:

"to ensure that the many success stories in the Welsh SME community are promoted locally and nationally. The SWCC Business awards provides an avenue for the story of the SMEs to be heard".

The SWCC wanted to recognise the achievements of all Welsh businesses along with the economic contribution they made to Wales/UK. The ultimate aim of the SWCC was to promote Welsh businesses in many different forums. Another objective was to promote Wales as a place to do business. Thus rewarding achievements of Welsh SMEs should increase confidence within the businesses themselves. According to the director of the SWCC, the business awards have evolved in the last five years. For example the business awards now encompass the whole of Wales and is now using the British Chamber of Commerce network. The use of this network led to an increase in the number of businesses being operated in Wales. Due to the increase in businesses, the SWCC simplified its 
processes and offered them the opportunity of more widespread recognition and promotion. One example of the simplified process of the scheme is to automatically submit entrants into the SWCC awards. The Director of the SWCC considers the publicity and the promotion the winners of the business award receive as the main benefit and states:

\author{
"The winners will have received regional or even national recognition of their \\ successes and achievements which they can utilise positively in the future to help the \\ further growth of their businesses."
}

The winning companies gave positive feedback about the business awards of the SWWCC. Business award winners state that they have been able to share the businesses success with all members of staff. Furthermore, they experienced a boost in the morale of their employees. The SWCC regards business awards especially in a difficult economic climate as important because it stimulates activity for continued success.

\title{
Conclusions
}

In conclusion, it was apparent that the value and impact an SME can obtain from winning a business award can be divided into macro (external parameters) and micro (internal parameters) impacts (see Figure 1). The micro view can be further divided into hard and soft measures. Hard measures are all the parameters which are measurable with numbers, for example impact upon profit and sales. In comparison, soft measures, like employee wellbeing or motivation, cannot be measured objectively. Figure 1 highlights the expected impacts of business awards on SMEs. Overall, there was a positive economic impact in both the micro and macro perspectives of SMEs. A variety of impacts were apparent across the 
case studies. Typically, the impact depended on the nature of business and other factors, such as marketing or the nature of their clients.

As a conclusion, the theoretical framework presented in Figure 1 has to be adapted to accurately represent the research findings. Thus Figure 2 provides a more accurate representation of the hard and soft measures that occur when an SME wins a business award.

\section{SEE FIGURE 2 HERE}

All SMEs within this study had used the business award successfully and started to promote it directly after winning. For example, Enterprise $\mathrm{H}$ sent out emails to clients and suppliers immediately upon winning the award to inform them. Several of the SMEs used public relations and the Internet to aggressively promote the business award. They put out press releases, promoted the award on the website, employed search engine optimization to inform the public about the business award. Another key characteristic of SMEs that have successfully exploited winning a business award is that they had previously won several business awards. Therefore, it can be assumed that SMEs with experience of prior award wins have enhanced knowledge and ability of how to exploit the award thereafter. Furthermore, these SMEs used the business award internally to motivate their employees and to increase the "feel-good" factor in the business. On each occasion they announced the winning of a business award and congratulated their employees. However, the successful exploitation of a business award is also dependent on the market the company operates in and on the current economic situation. Economic recession might negate some of the potential benefits of an award and several of the case studies noted that this might influence their decision whether to apply for a business award. 
Therefore, winning a business award has to be promoted in the appropriate manner but there are always other influences, like the market and the current economy, which influence the extent of the impact. In terms of best practice for business award providers several key factors were identified from interviews with SMEs and the SWCC and. Firstly, the application process for the business awards should be straightforward and not overly time consuming. Secondly, a range of business award categories should be available including current issues such as environmentally sustainability and ethical behaviour. Moreover, different categories provide more enterprises the opportunity to apply for a business award and give the business awards more substance.

Hendricks and Singhal (1996) found that the win of a quality award has a positive impact on the industry as a whole, because the stock market typically reacts positively. This study noted a similar trend in confirming positive external impacts of winning a business award on SMEs are noted. However, the impact was dependent on the business activity of the SME and the way it exploited the winning of the business award. With a high use of marketing and public relation tools to promote the business award, the awareness and the impact of the win increased. According to Pratt (2007) business awards can provide good publicity and enhance the public relations value. SMEs especially can benefit from business awards to gain enhanced recognition and credibility in the market (Zahorsky, 2012). Additionally, winners of the Queen’s Award for Enterprises experienced extra press coverage and an added commercial value (The Queens Awards for Enterprise Magazine, 2012). This study came to a similar conclusion. SMEs gain public attention and they experienced an increasing brand identity and an enhanced business profile. The business award is utilised for marketing purposes, for example on a website. The interviewed SMEs stated that the extra press coverage was a positive consequence of winning a business award. Therefore, it can be 
confirmed that award winning SMEs benefit from a similar impact in terms of enhanced publicity and public relations value (Pratt, 2007; the Queens Awards for Enterprise Magazine, 2011; Zahorsky, 2012).

Wang et al, (2004) state that winning a business award could have a positive impact on customers' trust for small online retailers whilst Wilson (2004) identified an increasing customer awareness of enterprises. Zahorsky (2012) states that there exists an increase in credibility and awareness for businesses when they win an award. This study revealed that winning a business award had a positive impact on customer networks and development of SMEs. Furthermore, customers provided good feedback about winning the award and their awareness was increased. This suggests that winning a business award increases customer trust for SMEs. Previous studies discovered that winning a quality award leads to an improvement in financial performance and an increase in sales (Boulter et al, 2005, Zahorsky, 2012). Similarly, this study identified a positive impact on the SMEs' turnover after winning a business award. An improvement in profitability could not be confirmed. Therefore, further research is required to analyse the financial changes and the profitability of SMEs after winning a business award. The interviewed SMEs suggested that a significant contributory influence could be the economic environment which might limit the impact of winning a business award.

This study noted that brand identity and business profile changed positively after winning a business award. This, combined with the higher customer awareness, can lead to enhanced competitiveness. Thus, this study supports the findings of Wilson (2004), that a business award enhances business competitiveness. More than $50 \%$ of the winners of the Queen's Award for Enterprises in 2011 experienced an enhanced recognition in international 
markets after winning an award (The Queens Awards for Enterprise Magazine, 2012). The respondents of this study did not experience a significant impact in international trading markets. These SMEs were typically operating mainly in Wales and did not promote the business award internationally. The winners of the Queen's Award for Enterprises stated that the employee engagement rose (The Queens Awards for Enterprise Magazine, 2012). Although the interviewed SMEs observed higher employee motivation and satisfaction, a positive impact on the attraction and retention of talent (Zahorsky, 2012) or an increase in quality of qualified applicants (Great Place to Work, 2012) was not experienced by the SMEs within this study.

Winners of a Business Award of the Great Place to Work Institute affirmed higher efficiency, creativity and innovative strength within their enterprise (Great Place to Work Institute, 2012). This study cannot confirm an impact on the efficiency, creativity or on the innovative strength. The interviewed SMEs did not experience a change in new product/service development. However, there exists a positive increase in employee motivation, which could lead to an increase in employee creativity. Wilkes and Dale (1988) study found that SMEs did not have time, resources or knowledge to apply for business awards. This study investigated how SMEs experienced the application process of the SWCC business award. The process was regarded as demanding, but not overly demanding. The interviewed SMEs acknowledged that the process is time consuming, but they would all apply again because of the value of winning a business award. Furthermore, the SMEs stated that the SWCC application process was in comparison with other business award application processes, not overly time consuming. The discussion is based on the minimal literature existing about the impact or value of business awards. This study could approve a general positive impact of winning a business award for SMEs. However, previous studies 
demonstrated that enterprises benefit in terms of enhanced sales revenue and profitability, which could not be approved by this study. There are several possible explanations for this result. The different findings regarding the impacts could result from the fact that this study has its focus on SMEs and previous studies regarded all kind of enterprises. Furthermore, the economic situation could be a reason for different outcomes. Further research is recommended.

The findings enabled the identification of key characteristics of SMEs that have successfully exploited winning a business award. The study revealed four such characteristics. The first is the promotion directly after the winning of the business award by, for example, sending out e-mails to clients and suppliers. The second characteristic is the use of public relations and marketing tools, such as press releases or website promotion. The third key characteristic is the on-going participation in and therefore the winning of various business awards. Successful SMEs gain experience and enhanced awareness through participating in business awards. The last characteristic is internal promotion. SMEs that exploited their business award successfully used it as an internal motivator. These key characteristics can be adapted by other SMEs and be used as guidelines for successful post award promotion. Figure 3 illustrates a summary of the key characteristics identified.

\section{SEE FIGURE 3 HERE}

\section{Research Implications}

In terms of the identification of best practice for business award providers the following recommendations can be made: 
1. The business award application process should be as straightforward as possible in terms of administration. The application process should involve a face to face interview with participants.

2. The business award should be available in a wide geographical area.

3. Different business award categories should be offered to give all kinds of businesses the opportunity to participate.

4. The businesses should be the main focus of the business award competition and the aim should be to promote and financially support them.

This study has significance for both SMEs and business award providers. The results enhance a limited literature base examining the impact of business awards on the SME community. Currently, the value of winning such business awards for an SME is relatively unknown. The results of this study will enable the SME community to further understand the value of winning a business award. Furthermore, SMEs will find out how such an achievement should be exploited to enhance enterprise profitability, employee motivation and the brand value. This study suggests that SMEs should consider the recommendations illustrated in Figure 3. Furthermore, the business award community will receive an enhanced understanding of such awards to SMEs. Business award providers can promote their awards more effectively due to the results of this study. The investigated value and impact that SMEs attain from winning a business award is therefore of value for business award providers. They can use the information and recommendations of the interviewed SMEs to enhance the business award process and respond to their needs and requirements. 


\section{Research Limitations and Recommendations for further research}

The following limitations should be noted in this study. Firstly, this study only focused upon winners of the SWCC business awards. Further studies could encompass a range of business awards to enhance the research validity. Secondly, this study did take place in an economically difficult time, which could have influenced the results of the study. Thirdly, the study took place in only within the Wales, due to the limited time schedule and resources of the study. Further research is required in both a national and international basis especially because this is the first study concerning SMEs and business awards. Therefore, further quantitative and qualitative research are required to provide additional empirical evidence.

\section{References}

Benbasat, I., Goldstein, D., and Mead, M. (1987), 'The Case Research Strategy in Studies of Information Systems', MIS Quarterly, Vol 11, No 3, pp 369-386.

Boulter, L., Bendell, T., Hanida, A., Dahlgaard, J. and Singhal, V. (2005), 'Report on EFQM and $\mathrm{BQF}$ funded study into the impact of the effective implementation of organisational excellence strategies on key performance results', The Center of Quality Excellence, Leicester.

Cavaye, A. (1996), 'Case Study Research: a Multifaceted Research Approach for IS', Information Systems Journal, Vol 6, No 1, pp 227-242.

Chau, S. (2003), 'The Use of E-Commerce amongst Thirty-Four Australian SMEs: an Experiment or a Strategic Business Tool?', Journal of Systems and Information Technology, Vol 7, No 1, pp 49-66.

Dana, L. P. (1988), 'The Spirit of Entrepreneurship and the Commonwealth Government of Australia', Journal of Small Business Management, Vol 26, No 1, pp 63-65. 
Darke, P., Shanks, G., and Broadbent, M. (1998), 'Successfully Completing Case Study Research: Combining Rigour, Relevance and Pragmatism', Information Systems Journal, Vol 8, No 4, pp 273-289.

Department for Business Innovation and Skills (DBIS) (2011), 'Business population estimates for the UK and regions', Department for Business Innovation and Skills, 8, p 16.

Frey, B. (2007), 'Awards as compensation', European Management Review, Vol 4, No 1, pp 6-14.

Frey, B., and Neckermann, S., (2007), 'Awards as Incentives.' IEW Working Paper No 334, Institute for Empirical Research in Economics, University of Zurich.

Frey, B., and Neckermann, S. (2008), 'Awards: A view from psychological economics.' Journal of Psychology, Vol 216, No 4, pp 198-208.

Gavrila, C., Caulkins, J., Feichtinger G., Tragler, G., and Hartl, R. (2005), 'Managing the Reputation of an Award to Motivate Performance', Mathematical Methods of Operations Research, Vol 61, pp 1-22.

Great Place to Work Institute (2012), Vertrauen führt zu größerer Produktivität und Rentabilität, website: http://www.greatplacetowork.de/great/ergebnisse.php. (accessed 21 May 2012).

Hansen, W. L., and Weisbrod, B. (1972), 'Toward a General Theory of Awards, or, Do Economists Need a Hall of Fame?', Journal of Political Economy, Vol 80, pp 422-431.

Hendricks, K., and Singhal, V. (1996), 'Quality awards and the market value of the firm: An empirical investigation', Management Science, Vol 42, No 3, pp 415-436.

Heppner, P. P., and Pew, S. (1977), 'Effects of diplomas, awards, and counselor sex on perceived expertness', Journal of Counseling Psychology, Vol 24, pp 147-149. 
Ichniowski, C., and Shaw, K. (2003), 'Beyond Incentive Pay: Insiders' Estimates of the Value of Complementary Human Resource Management Practices', Journal of Economic Perspectives, Vol 17, No 1, pp 155-180.

Johannessen, J.-A., Olaisen, J., and Olsen, B. (1999), 'Strategic Use of Information Technology for Increased Innovation and Performance', Information Management and Computer Security, Vol 7, No 1, pp 5-22.

Jones, P., Packham, G., Beynon-Davies, P., Simmons, G., and Pickernell, D. (2013) An Exploration of the Attitudes and Strategic Responses of Sole-Proprietor Micro-Enterprises in Adopting ICT, International Small Business Journal, forthcoming.

Magnus, M. (1981), 'Employee recognition: A key to motivation', Personnel Journal, Vol 60, pp 103-107.

Markham, S. E., Scott, K., and McKee, G. (2002), 'Recognizing Good Attendance: A Longitudinal, Quasi-Experimental Field Study’, Personnel Psychology, Vol 55, pp 639-660.

Nalebuff, B. J., and Stiglitz, J. E. (2001) 'Prizes and incentives: Towards a general theory of compensation and competition.' Bell Journal of Economics, Vol. 14, pp. 21-43.

Nelson, B. (2005), 1001 ways to reward employees, Workman, New York.

Neckermann, S., Cueni, R., and Frey, B. (2009), What is an Award Worth? An Econometric Assessment of the Impact of Awards on Employee Performance, IEW Working Paper 411, University of Zurich.

Neckermann, S., Cueni, R., and Frey, B. S., (2012), Awards at Work, ZEW - Centre for European Economic Research, Discussion Paper No. 12-004, website: http://ssrn.com/abstract=1997147 or http://dx.doi.org/10.2139/ssrn.1997147 (accessed 20 September 2012).

Partington, D. (2002), Essential Skills for Management Research, Sage Publications, London. 
Patton, M. Q. (1990), Qualitative Evaluation and Research Methods (2 ${ }^{\text {nd }}$ Edn.), Sage Publications, Newbury Park, CA.

Poon, S., and Swatman, P. (1999), 'An Exploratory Study of Small Business Internet Commerce Issues', Information and Management, Vol 35, No 1, pp 9-18.

Pratt, A. (2007), 'Respect for the gladiators', Director, Vol 60, No 6, p 16.

Rowley, J. (2002), 'Using Case Studies in Research', Management Research News, Vol 25, No 1, pp 16-27.

Tait, R., and Walker, D. (2000), 'Motivating the work force: The value of external health and safety awards', Journal of Safety Research, Vol 31, pp 243-251.

Thietart, R. A. et al, (2001), Doing Management Research - A comprehensive guide, Sage Publications, London.

Salkind, N. J. (2003), Exploring research (5th Ed.), Prentice Hall, Upper Saddle River, N. J.

Schlenker, L., and Crocker N. (2003), 'Building an E-Business scenario for small business: the IBM SME Gateway project', Qualitative Market Research: an International Journal, Vol 6, No 1, pp 7-17.

Smith, N. G. (1991), 'The Case-Study: a Vital Yet Misunderstood Research Method', in Smith, N. G., and Stake, R., eds, The Art of Case Study Research, Sage Publications, London.

The Queens Award for Enterprise Magazine (2012), Why Advertise? Queens Award Magazine, website: http://www.queensawardsmagazine.com/why-advertise (accessed 13 May 2012).

Voisey, P., Gornall, L., Jones, P., and Thomas, B. (2005), 'Developing a model for a 'ladder of incubation' linked to Higher and Further Education Institutions in Wales', Industry and Higher Education, Vol 19, No 6, pp 445-456. 
Wang, S., Beatty, S. E., and Foxx, W. (2004), 'Signalling the trustworthiness of small online retailers', Journal of Interactive Marketing, Vol 18, No 1, pp 53-69.

Wilkes, N., and Dale, B. (1988), 'Attitudes to self-assessment and quality awards: A study in small and medium-sized companies', Total Quality Management, Vol 9, No 8, pp 731-739.

Wilson, J. P. (2004), 'An examination of the economic benefits of ISO 9000 and the Baldrige award to manufacturing firms', Unpublished $\mathrm{PhD}$ dissertation, University of Pittsburgh. Yin, R. (1994) Case study Research: Design and Methods (2nd edn). Newbury Park, CA: Sage.

Zahorsky, D. (2012), The American Business Awards: The Value of Corporate Awards, website http://www.stevieawards.com/pubs/general/72_194_8831.cfm. (accessed 21 May 2012). 


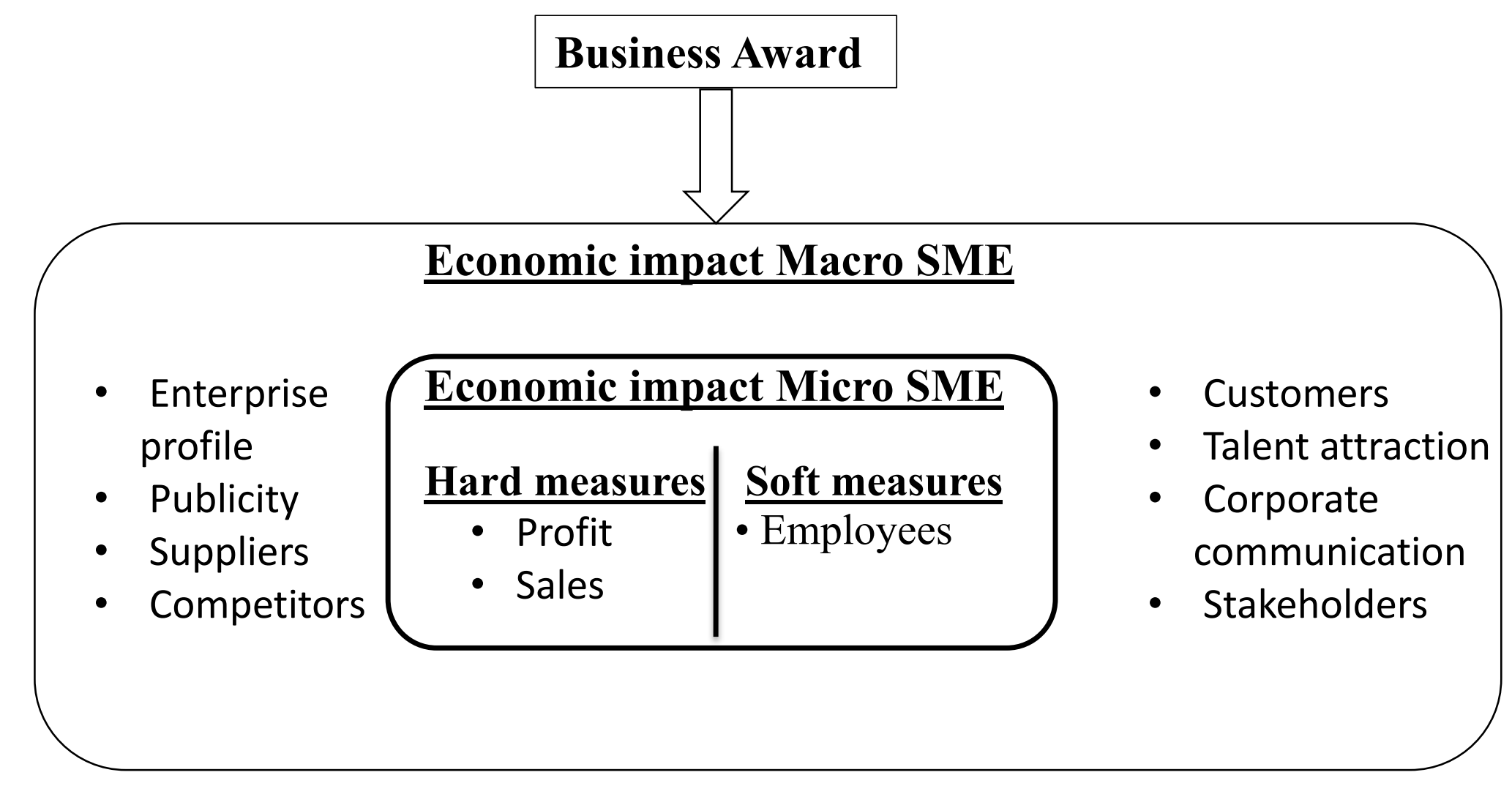

Figure 1: Analytic framework 


\section{Economic impact}

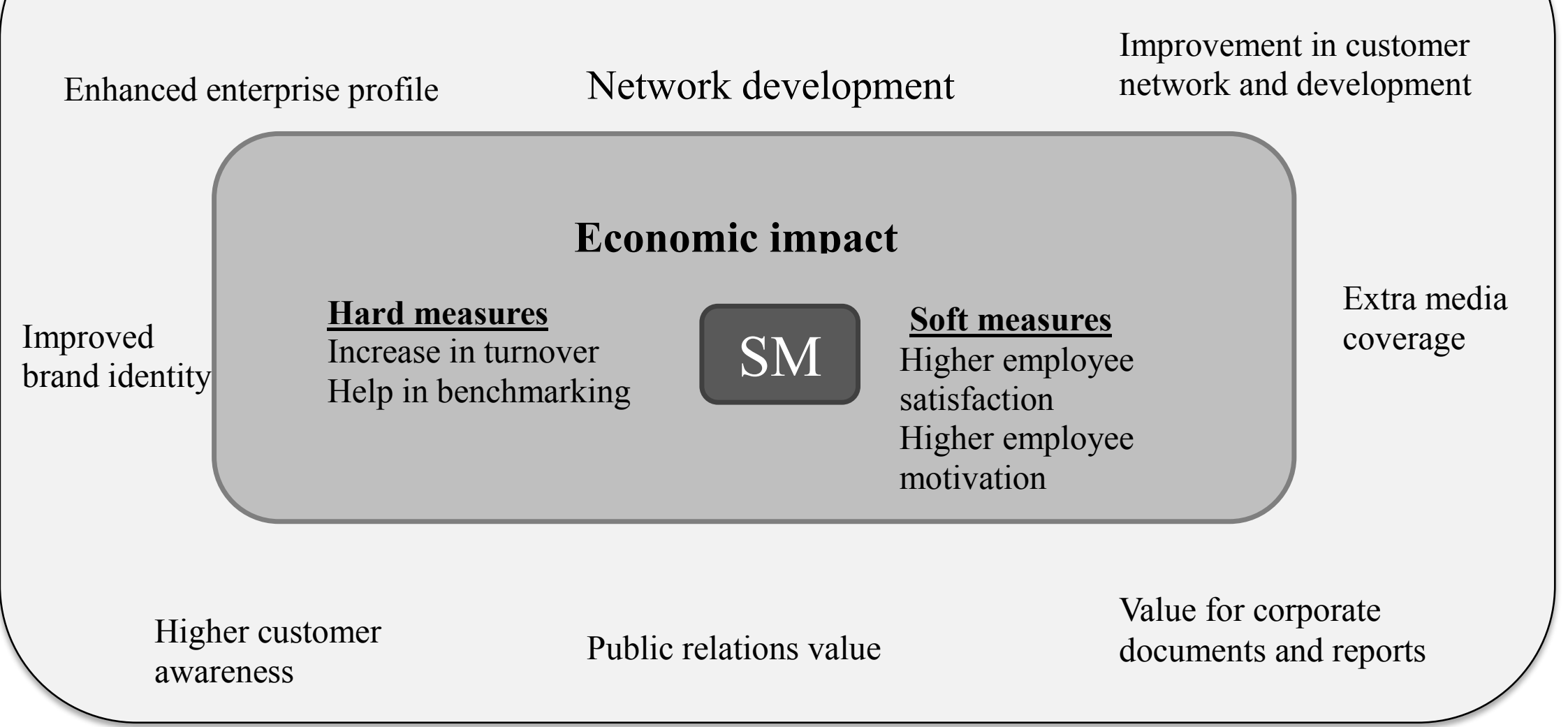

Figure 2: The Impact of winning a business award on an SME 


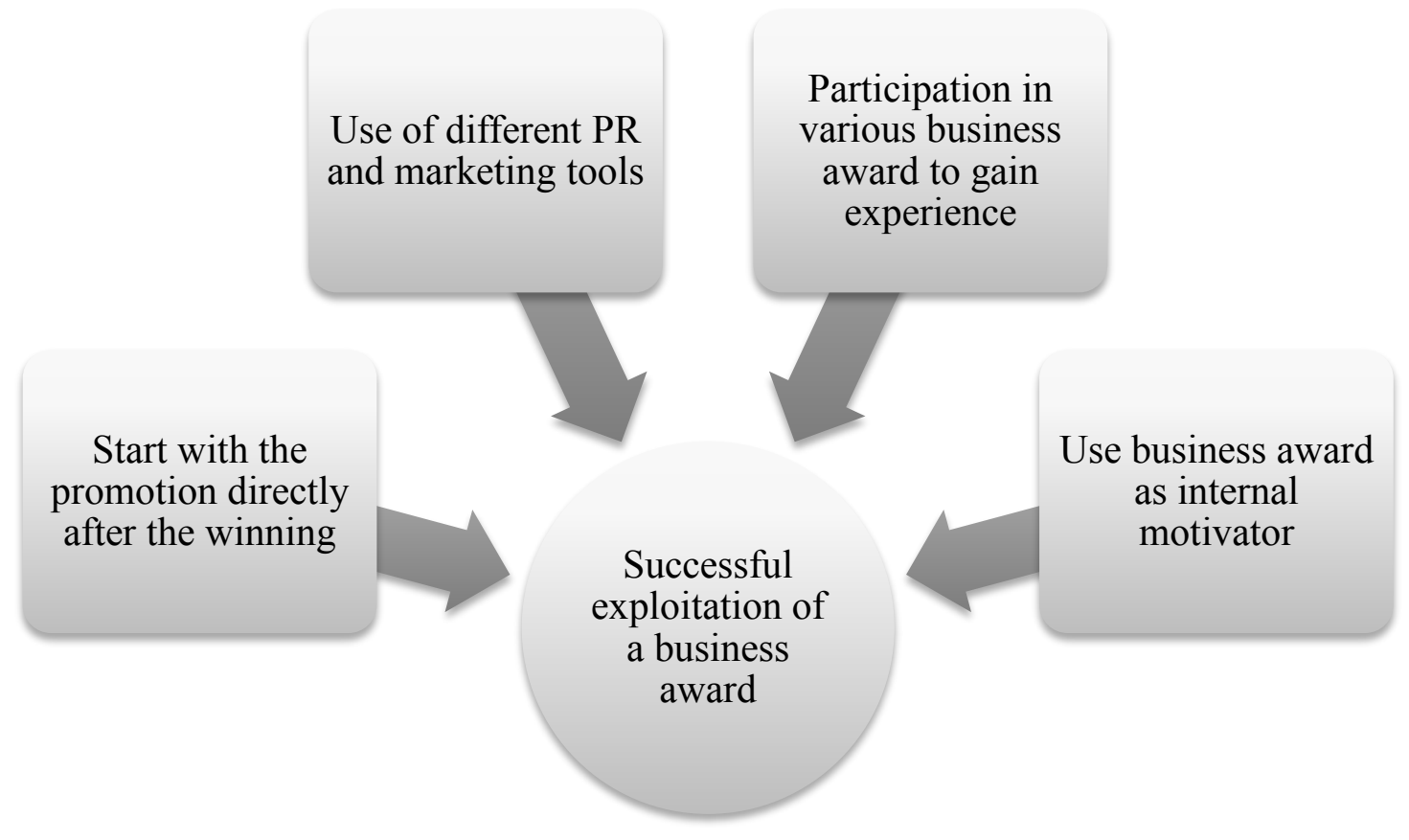

Figure 3 Successful exploitation of a business award 